\title{
Jatropha curcas as feedstock for green fuels production
}

\begin{abstract}
An increasing demand of energy and fuels for diverse applications, in addition to the depletion and negative effects of fossil resources, has raised the interest to use nonedible biomass or residual biomass as alternative raw material to produce renewable fuels for heavy vehicles. Currently, several projects around the world aim the sustainable production of green fuels and a major challenge to overcome is to guarantee the continuous supply or biomass required as raw materials. To this purpose, non-edible vegetable oils, such as Jatropha curcas $(J C)$ oil, have been suggested as a very favorable feedstock. In this review, we briefly summarized the potential to produce $J C$ seeds and oil in Mexico as well as the outcomes and challenges found when $J C$ oil was used to biodiesel production. We also identify some the actions required to establish a $J C$ supply chain, which is a basic premise to promote the development of green liquid fuels such as sustainable aviation fuel.
\end{abstract}

Keywords: Jatropha curcas, bioenergetics, green fuels, biodiesel, sustainable aviation fuel
Volume 5 Issue I - 2021

\author{
Marco A Sánchez-Castillo,' José de Jesús \\ Esparza Claudio, ${ }^{2}$ Miguel Ángel Angulo \\ Escalante, ${ }^{3}$ Claudia del Rocío Arellano del \\ Rio,' L Fabiola Palomo González' \\ 'Facultad de Ciencias Químicas, Universidad Autónoma de San \\ Luis Potosí, Mexico \\ ${ }^{2}$ Centro de Innovación Aplicada en Tecnologías Competitivas, \\ Mexico \\ ${ }^{3}$ Centro de Investigación en Alimentación y Desarrollo AC, \\ Mexico
}

Correspondence: Marco A Sánchez Castillo, Universidad Autónoma de San Luis Potosí, San Luis Potosí, México,

Tel +52-444-8262300 Ext 6566, Email masc.ciacyt@gmail.com

\section{Introduction}

In the last decades, rise of world's population and society concerns to improve social and economic welfare have detonated a significant increase of energy and fuels for domestic, industrial and transportation needs. ${ }^{1}$ For example, it is expected that in 2040 the demand for diesel and jet fuel will be increased by 30 and $50 \%$, respectively. ${ }^{2}$ On the other hand, it is well established that fossil sources used to generate energy and liquid fuels are being depleted; in addition, these sources contribute to emission of greenhouse gases (GHG) causing drastic harm to health and environment. In United States around 30\% of total GHG are due to transportation sector and in Mexico GHG theses emissions will be around $28 \%$ by $2030{ }^{3,4}$ Therefore, multiple international agreements have been established to mitigate climate impact by reducing GHG emissions from transportation sector. ${ }^{5}$ Over the last 2 decades, there has been a strong incentive to develop alternatives to replace conventional fuels for light and heavy vehicles. In the mid-term, electrical and solar energy based light vehicles seem to be a suitable option, but these strategies are not technologically and economically convenient for heavy vehicles; to this purpose, renewable liquid fuels such as biodiesel and bio jet fuel are produced from non-edible oilseed biomass seem to be the top choice. To date, these fuels are being are being commercialized and the technologies focus on the development of green fuels that can be directly used in the current combustion engines. ${ }^{6}$ However, bio fuels commercialization is very asymmetric around the world due to numerous and complex technological, economic and/or political barriers, which are solved in different ways in each region. In almost all cases, a very challenging task is to guarantee the supply of biomass required as raw material. For these reason the optimization of the cultivation process of nonedible oilseed biomass is a very relevant issue. ${ }^{7,8}$

\section{Analysis}

Jatropha Curcas (JC) cultivation has widely spread worldwide since the late $1990 \mathrm{~s}$, when its promising potential as a bioenergetic was recognized. JC is native to Mexico, Central and South America, Africa and India. ${ }^{9,10}$ However, most of the Jatropha plantations are located in Asia $(85 \%)$ and to a lesser extent in Africa (13\%), with a growing increase in the areas planted with Jatropha in America (2\%). ${ }^{7,11} J C$ is a fast-growing small tree or large perennial shrub that reaches a normal height of 2 to $3 \mathrm{~m}$ and whose productive life ranges between 45 to 50 years. ${ }^{12,13} \mathrm{JC}$ cultivation is favored by tropical or subtropical climate over a relatively broad set of environmental conditions: an average annual temperature of 18 to $40{ }^{\circ} \mathrm{C}$, altitudes of 500 to 2150 mamsl, rainfalls of 300 to $3,000 \mathrm{~mm}$. $J C$ grows almost anywhere, although it prefers loamy-sandy-clayey soils, with soil depth not less than $45 \mathrm{~cm}$ and it requires soil nutrients such as nitrogen, phosphorus, and potassium. ${ }^{12,14} J C$ seeds are typically develop for 3 months in a greenhouse before they are transplanted to field. ${ }^{4,15}$ Five years old $J C$ yields seeds from 0.1 to 15 ton/ha/year seeds and an average oil yield around $1590 \mathrm{~kg} / \mathrm{ha} /$ year. ${ }^{16,17} \mathrm{JC}$ is a non-edible (toxic) oil that contains a high level of oleic and linoleic fatty acids and its main applications include the production of soap, biocides and biodiesel, which consist of a mixture of fatty acid alkyl esters. ${ }^{18,19}$

Mexico has a privileged opportunity to produce $J C$. In the last two decades, the Mexican government promoted and financially supported different initiatives to cultivate $J C$ as raw material for biodiesel production with the main goal of reducing GHG, but also as an alternative to create better jobs and wages for farmers and to promote the development of rural areas. ${ }^{20,21}$ A detailed study was conducted in Mexico to evaluate the potential availability of $J C$ crop, based on official data reported by SAGARPA (Mexican Agriculture Agency), as well as surveys and field visits to $J C$ producers $^{22}$. Data included in Table 1 showed that Mexico has the potential to detonate an advantageous supply chain of $J C$ oil to be used for bio fuels production. The highest $J C$ oil production potential was validated for state of Chiapas, which represents $35 \%$ of the total production, with an estimated 121,037 ton of $J C$ oil per cycle, followed by Jalisco d Michoacán with $28 \%$ and 24\%. ${ }^{22}$ 
Table I Jatropha seed and oil production potential in Mexico (adapted from reference 22)

\begin{tabular}{llll}
\hline State or region & Sustainable Area $(\mathrm{ha})$ & Estimated JC production at 4 year (ton/y)* & Estimated JC oil yield (ton/y)** \\
\hline Chiapas & $87,708.09$ & $2,63,124.27$ & $1,21,037.16$ \\
Guanajuato & 128.21 & 384.63 & 176.93 \\
Hidalgo & $2,296.11$ & $6,888.33$ & $3,168.63$ \\
Jalisco & $70,441.23$ & $2,11,323.69$ & $97,208.90$ \\
Michoacán & $61,012.13$ & $1,83,036.39$ & $84,196.74$ \\
Sinaloa & $31,945.93$ & $95,837.79$ & $44,085.38$ \\
\hline
\end{tabular}

$*$ Seed production used as reference $=3 \mathrm{t} / \mathrm{ha}$. $* *$ Average oil yield $=46 \%$

The Mexican government made relevant efforts to spread JC cultivation in different edapho climatic regions, taking advantage that Jatropha is a highly adaptable crop that grows in marginal soils, resists drought, diseases and some pests reasonably well, and require relatively lower agronomic practices. ${ }^{8}$ Mexican agriculture research centers enhanced JC native variety to increase $J C$ seeds and oil production according to local soil and climate conditions. ${ }^{5}$ This favorable scenario motivated Mexican farmers to switch from bean and maize to $J C$ cultivation ${ }^{23,24}$ and some local and foreign private companies promoted $J C$ oil production at pilot plant scale. ${ }^{5}$ However, despite all investments and favorable potential, benefits from $J C$ seed and oil production in Mexico were very limited, especially for rural areas. One of the key factors for this drawback was that $J C$ seeds and oil yields were lower than expected, ${ }^{25}$ suggesting the need to implement and respect standardized $J C$ cultivation practices. On the other hand, there was no sustained growth in $J C$ oil demand because the biodiesel value chain failed to consolidate in Mexico. Several private biodiesel pilot plants were unable to scale production due to the lack of government's fiscal and economic incentives, reduced private stakeholder's involvement and low demand from Mexican biodiesel market. ${ }^{26}$ These issues, associated with the fact that biodiesel had to be blended with fossil diesel, made uncompetitive the biodiesel business and most of biodiesel companies established in Mexico were forced out of business.$^{27}$ A similar outcome occurred in several other developing countries, where it was not possible to launch a sustainable biodiesel production from $J C$ oil. ${ }^{25}$

In this scenario, private and public actor in the aviation industry detonated an international commitment to mitigate the negative environmental impact caused by the use of conventional jet fuel. One of the most important initiatives was to developed sustainable aviation fuels (SAF) using non-edible biomass as raw materials. ${ }^{7,28}$ To this purpose, UOP/Honeywell, Neste, Byogy, Lanzatech, among several other companies, are simultaneously developing technologies to produce SAF by means of the HEFA (Hidro processed Esters and Fatty Acids) process and the ATJ (Alcohol to Jet) process, which required non-edible vegetable oils and ethanol produced from residual lingo cellulosic biomass as raw materials, respectively. ${ }^{29,30}$ The approached revitalized the interest in $J C$ seed and oil production worldwide. In Mexico there have been various initiatives to validate the use of $J C$ oil for SAF that, complying international standards, could be directly used in the current engines of aviation industry; these are the so-called "drop-in" or green fuels. Recently, the "Bioturbosina cluster" (BC), a research center based consortium financed by the Mexican government established the basis of a value chain for sustainable JC production. ${ }^{31}$ $\mathrm{BC}$ also promoted the joint production of $J C$ and Castor oil, and made preliminary validation of the production of Salicornia oil in arid and semi-arid regions of Mexican territory. BC clearly showed that a successful $J C$ production value chain must include the optimization of the $J C$ variety, as well as the cultivation, harvesting and oil extraction conditions. The development of technological packages to standardize the productivity of $J C$ seeds and oil was other relevant product of $\mathrm{BC}$ that may now be transferred to local producers. To date, the indicated approach for $J C$ seeds and oil production may now be incorporated as a key resource for the SAF production value chain.

Very importantly, a mid- and long-term strategy for SAF production in Mexico, as it could be the case in other developing countries cannot be local; rather, it must be the result of a state policy that strongly promotes the development of green liquid fuels. Operationally, it must include the participation of public and private sectors; companies associated with the aviation sector operating in the country should be considered as strategic allies in the development of the supply chain. It is also imperative the formal establishment of technical, environmental, economic and legal policies, strategies and programs, to promote:

The recovery of eroded, deforested or degraded land in productive areas.

The development of improved $J C$ variety according to of climate and edaphic conditions of each region, including the alternative of genetically modified varieties.

i. The optimization of agricultural production process, focused on productivity and market profitability.

ii. The validation of local cultivation practices to promote sustainable process.

iii. Development of technological packages for producers.

iv. The promote the active participation of producers in the supply chain.

v. The mechanization of field processes.

vi. The logistics of seed collection and transport.

vii. The optimization of $J C$ oil extraction methods.

viii. The recovery and valorization of waste from $J C$ harvesting and processing.

ix. Subsidies and economic and fiscal incentives for $J C$ production and extraction processes.

\section{Final considerations}

The establishment of a SAF production value chain requires a harmonious integration of public policies, technological development strategies, and effective cooperative programs between technicians, 
producers, and public and private entities. An appropriate integration of the links in the $J C$ seeds and oil supply chain is a challenge when not formal federal policies are set. In this case, the creation of local supply chains remains as a feasible alternative as a proof of concept and as a source of valuable data to raise interest among private investors. It is clear that supply of bioenergetics represents a great opportunity for developing countries to promote sustainable development and social welfare in the immediate future.

\section{Acknowledgments}

The authors thank the "Bioturbosina Cluster" and CONACYT for the financial support of the project associated to this mini review.

\section{Conflicts of interest}

Authors declare no conflict of interest.

\section{References}

1. Bórawski P, Bełdycka-Bórawska A, Szymańska EJ, et al. Development of renewable energy sources market and biofuels in The European Union. Journal of Cleaner Production. 2019;228:467.

2. Mohammad Al herbawi Gordon McKay Tareq Al-Ansari, Jatropha curcas for jet biofuel production: Current status and future prospects. Renewable and Sustainable Energy Reviews. 2021;135:110396.

3. United states environmental protection agency.

4. Lopez G, UcVárguez A, Jatropha curcas en méxico: avances y perspectivas de un cultivo bioenergético. Yucatan, México. 2018

5. Antwi-Bediako R, Otsuki K, Zoomers A, et al. Global investment failures and transformations: a review of hyped jatropha spaces, sustainability. MDPI. 2019;11(12):1.

6. Douvartzides S, Dimitrios N, Papageridis K, et al. Green diesel: biomass feedstocks, production technologies, catalytic research, fuel properties and performance in compression ignition internal combustion engines energies. MDPI. 2019;2:4.

7. Nirza Fabiola, Castro Gonzáles, International experiences with the cultivation of Jatropha Curcas for biodiesel production. Energy. 2016;112:1245

8. Ewunie GA, Morken J, Lekang OI, et al. Factors affecting the potential of Jatropha Curcas for sustainable biodiesel production: A critical review. Renewable and Sustainable Energy Reviews. 2021;137:110500.

9. Heller J, Jatropha curcas L. Promoting the conservation and use of underutilized and neglected crops. Physic Nut. Rome: International Plant Genetic Resources Institute. 1996.

10. SilitongahA S, Masjuki H, Chong WT, A global comparative review of biodiesel production from jatrophacurcas using different homogeneous acid and alkaline catalysts: Study of physical and chemical properties. Renewable and Sustainable Energy Reviews. 2013;24: 514.

11. Martın C, Moure A, Martı G, et al. Fractional characterization of Jatropha, neem, moringa, trisperma, castor and candlenut seeds as potential feedstocks for biodiesel production in Cuba. Biomass Bioenergy. 2019;34:533

12. Martha N, Riera O, Biodiesel value chain and access to energy in Ethiopia: policies and business prospects. Renew Sustain Energy. 2014;39:975-985.
13. Gabisa EW, Gheewala SH, Potential, environmental, and socio-economic assessment of biogas production in Ethiopia: the case of Amhara regional state. Biomass Bioenergy. 2019;122:446.

14. Jingura RM, Matengaifa R, Musademba D, et al. Characterization of land types and agro-ecological conditions for production of Jatropha as a feedstock for biofuels in Zimbabwe. Biomass Bioenergy. 2011;35(5):2080.

15. Calzada, J, Narvaez J, Luna S, et al. Planeación agrícola nacional 20172030. ciudad de méxico: secretaria de agricultura, Ganadería, Desarrollo Rural, Pesca y Alimentación. 2017.

16. Silitonga AS, Atabani AE, Mahlia TM I, et al. A review on prospect of Jatropha curcas for biodiesel in Indonesia. Renewable and Sustainable Energy Reviews. 2011;15(8):3733.

17. Mofijur M, Masjuki HH, Kalam MA, et al. Prospects of biodiesel from Jatropha in Malaysia. Renewable and Sustainable Energy Reviews. 2012;16(7):5007.

18. Achten WMJ, Verchot L, Franken YJ, et al. Jatropha bio-diesel production and use. Biomass and Bioenergy. 2008;32(12):1063.

19. Akbar E, Yaakob Z, Kamarudin SK, et al. Characteristic and composition of Jatropha Curcas oil seed from Malaysia and its potential as biodiesel feedstock. European Journal of Scientific Research. 2009;29(3):396.

20. Banerjee A, Halvorsen KE, Eastmond-Spencer A, et al. Sustainable development for whom and how? Exploring the gaps between popular discourses and ground reality using the Mexican Jatropha biodiesel case. Environ. Manag. 2017;59:912.

21. Montero G, Stoytcheva M, Coronado M, et al. An overview of biodiesel production in Mexico. in biofuels-status and Perspective, InTech: London, UK. 2015.

22. Esparza J, Catálogo de disponibilidad y potencial de biomasa para los procesos HEFA y ATJ. Clúster Bioturbosina, CIATEC AC. 2018.

23. Hinojosa FID, Skutsch M, Impact of establishing Jatropha Curcas to produce biodiesel in three communities of Michocan, Mexico, approached from different scales. Rev Geogr Am Cent. 2011;2:1.

24. Valero Padilla J, CortinaVillar HS, Vela Coiffer MP. The project of biofuels in chiapas: experiences of physic nut (Jatropha curcas) farmers within the rural crisis framework. Estud Soc. 2011;19:120-144.

25. Lama AD, Klemola T, Saloniemi I, et al. Affecting genetic and seed yield variability of Jatropha Curcas across the globe: a review. Energy for Sustainable Development. 2018;42:170.

26. Dias LAS, Missio RF, Dias DCFS. Antiquity, botany, origin and domestication of jatropha curcas (Euphorbiaceae), a Plant species with potential for biodiesel production. Genet Mol Res. 2012;11:2719.

27. Rodriguez OAV, Vazquez AP, Gamboa CM. Drivers and consequences of the first Jatropha Curcas plantations in Mexico. Sustainability. $2014 ; 6: 3732$.

28. https://www.iata.org/en/programs/environment/sustainable-aviationfuels/

29. Klein BC, Chagas MF, Junqueira TL, et al. Techno-economic and environmental assessment of renewable jet fuel production in integrated Brazilian sugarcane biorefineries. Applied Energy. 2018;209:290-305.

30. http://caafi.org/about/members.html

31. https://clusterbioturbosina.ipicyt.edu.mx/pagina/public/ 